\title{
Gastronomy Tourism in Several Neighbor Countries of Indonesia: a Brief Review
}

\author{
Kurniasih Sukenti \\ University of Mataram, Majapahit Street No.62, Mataram, Indonesia, and Doctoral Program in Biology Department of \\ Biology, Faculty of Mathematics and Natural Sciences, Brawijaya University, Malang, Indonesia
}

\section{Abstract}

Gastronomy tourism, also called culinary tourism or food tourism, is a kind of tourism that provide attractions based on the culinary aspect owned by a country, region, or area. It is not only offers food and beverages as the main objects in its attractions, but also everything related to food activities ranging from food ingredients, preparation, processing, serving, as well as the cultural and local values. A well-managed culinary tourism will be a supportive program in developing and enhancing the tourism sector in a country. The objective of this paper is to describe the profile of gastronomy tourism in several neighbor countries of Indonesia, i.e. Hongkong, Singapore, Thailand, and Malaysia. This brief review is also discussed the potential of Indonesia gastronomy in supporting government's tourism program. Basically, Indonesia has more enormous potential asset in managing its cultural heritages in term of culinary than its neighbor countries. A well-managed gastronomy tourism plays not only an important role in enhancing the economic sector, but also contribute in preserving the natural and cultural resources.

Keywords: gastronomy tourism, culinary tourism, neighbor countries of Indonesia

\section{INTRODUCTION}

Gastronomy tourism or culinary tourism is a kind of visit or trip based on the interest in food and beverages. People make a trip due to have an experience in tasting the culinary products that can provide an impression in their lifetime; thus, a unique and impressive culinary identity was an important asset for any succesful culinary tourism destination [1]; [5]; [21]. In 1998, Lucy Long introduced the term "culinary tourism" for the first time, refering to a tourism concept which tourists can experience the local culture of other countries by tasting their food [7]. Generally, traveling in the term of gastronomy tourism is always related to explore and enjoy the special cuisines which contain the destination's identity [7]; [21].

Gastronomy or culinary tourism is not just an activity associated with food and beverages, but it is also related to events and other culinary activities like festivals and visitations [1]; [2]. Culinary tourism or gastronomic tourism will continue to provide jobs for workers, services for the customer and opportunities for investors [3]; [22]. It is also a kind of constituent in tourism strategy dedicated to optimalize the use of available resources through creativity and adaptability, due to the

\footnotetext{
Corresponding Address:

Email : kurniasihsukenti@yahoo.com

Address : University of Mataram, Jl. Majapahit no. 62 Mataram - Nusa Tenggara Barat, INDONESIA
}

lack of conventional natural and cultural tourism assets [17]; [23].

Indonesia is a country endowed with diverse natural resources, tribes and ethnicities, cultures and traditions, as well as various other uniqueness that no other country has, especially in terms of culinary. Indonesian culinary is a portrait of the diversity of plants and animals, various way in processing and presentation, and absolutely richness in taste and culture. It is an advantage that many regions in Indonesia are also popular as tourist destination for both domestic and foreign tourists. Traditional culinary in Indonesia, which are consisted of various food, beverages and munchies is an enourmous potency to support Indonesia's tourism. Enjoying local cuisines can not be separated from tourist traveling activities. Therefore gastronomy with all its aspects is a great opportunity for Indonesia to introduce and promote not only the type of dish and constituent materials, but also the variety of processes, meanings and values existed in it. Culinary tourism can be developed into ecoculinary tourism level by adding values such as eco-friendly orientation, community involvement and educational content. With proper management, traditional Indonesian culinary is going to be one of the potential attraction for tourism in Indonesia, in addition to the natural beauty and hospitality of the people.

The objective of this brief mini-review is to describe and compare the profile of gastronomy tourism in several neighbor 
countries of Indonesia, i.e. Hongkong, Singapore, Thailand, and Malaysia. Hopefully this paper can give some images about how those countries managed their resources and capital to contribute in their national tourism sector optimally. Indonesia's gastronomy profile and it's chance in supporting tourism development will also be discussed here briefly.

\section{DISCUSSION}

\section{Gastronomy tourism in Hongkong}

Hongkong is a country whose wellmanaged and supportive gastronomic profile in its tourism sector. Basically, Hongkong does not have affluent natural resources to create various tourism attractions, but it does have a various food and cultural backgrounds which can be arranged into an inovative tourism that attracts people's attention. The geographical position is also play an important role in making the uniqueness of its multi-ethnic food cultures, which become the core resource in developing its culinary tourism [7]. Hongkong as a commonwealth country has a unique culture that combines western lifestyle with Chinese tradition. For foodies and culinary tourists, they will state that Hongkong is one kind of "food paradise", a suitable and promising place for food and dining out. This reputation has made Hongkong as one of Asia's most popular tourism destination [23], and being the key to the city's tourism industry [11]; [23]. Using indigenous and authentic Chinese cuisine as a strength point, Hongkong succeed in positioning its local food as a unique cultural marker. These all advantages are also being supported by a lot of efforts in promoting its culinary tourism. Sort of brochures, booklets and website provide detailed and appealing material and photos on gastronomic attributes in Hongkong [14]; [23], and these all give much important information for tourists in selecting and deciding where to go for dining out in Hongkong. Dim sum is one of major culinary culture in Hongkong [7], and it is famous all over the world. There are also some food districts (e.g. Causeway Bay, Kowloon city, Tsim Sha Tsui) which are effectively promoting Hongkong's culinary tourism resources by providing various food route. Food-related museums exhibiting tea culture [7], and some annual food festival are also being some supportive events in constructing the good athmosphere in culinary tourism in Hongkong (e.g. Best of the Best Culinary Awards).
Hongkong also realized that it does depend tightly on tourism. Therefore, the general public in Hongkong is very cooperative in terms of government tourism promotion activities, e.g implemented in free tourism advertising by their entertainers, or some programs from aviation company in encouraging travel and saving tourism when SARS epidemic hit Hongkong several years ago [7]. To ensure the tourist have high cuality cuisines, Hongkong have strict quality assurance certification system. This kind of regulation can make the certified restaurant become more famous, and the other hand the tourist can enjoy the quality-assured cuisine which give them a great impression and increase the possibility of their visiting again, even their promotion to others. Hongkong Tourism Board (HKTB) brought up the Quality Tourism Service (QTS) Scheme to raise overall service standards and visitors' confidence [7]. Restaurants indicated with QTS sign made tourists can easily identify where they can dining out in standardized quality; not only the cuisines, but also the services. Other effort by HKTB is worked with marketing research companies, and the results were analyzed to develop more effective marketing strategies.

From those facts, it seems clearly that Hongkong with its limitation in area and natural resources fully realize that it must do some efforts in developing and supporting tourims as its mainstay sector in economic. Hongkong has succeeded in exploiting its unique condition (combination of western lifestyle and traditional Chinese culture) through its gastronomical assets that managed well and seriously. All these efforts play an important role in making Hongkong be one of top culinary destination icons in Asia. Hongkong is also follow-up its advantages and assets in gastronomy continuously with conducting various gastronomy-based research, and use the results as references in developing its gastronomical asset for culinary tourism.

\section{Gastronomy tourism in Singapore}

Singapore is one of the famous tourismd estination in Asia and Singapore's cuisines is one of the important aspect to attract tourists [4]; [19]; [23]. The power of Singapore in tourism has been supported bu high quality of human resources and services. This s actualy similar with Hongkong. Singapore has the similarity with Hongkong. Ecologically, these ara realatively poor in natural resources to support diverse foods. Most of resources were imported from 
surrounding contries, including ndonesia. [6]; [23].

In Singapore, attracting tourist in cullinary has been promoted by slogan "Singapore: the Food Capital of Asia". "Food" and "dining out" is the important strategy to invite visitors to Singapore. [6]; [23]. In 2004, ten cuisines were determined as the top 10 representative food of Singapore. They are Satay (meat on a stick with onion and gravy along with it), Bak Kut Teh (meat bone soup with herb and spices), Chilli/Pepper Crab (stir-fried crab in a semi-thick, sweet and savoury tomato and chilli based sauce), Hainan Chicken Rice (chicken served with rice cooked in chicken oil), Roti Canai (a type of Indianinfluenced flatbread) \& Teh Tarik (hot Indian milk tea beverage), Laksa (spicy noodle soup from the Peranakan culture), Fish Head Curry (a dish where the head of an Ikan Merah (red snapper, literally "Red fish"), is semistewed in a Kerala-style curry with assorted vegetables such as okra and brinjals and usually served with either rice or bread), Fried Kuey Teow (stir-fried ricecake strips), Rojak (traditional fruit and vegetable salad), and Carrot Cake [7]. It is clearly that Singapore does make use of it's culture diversity on food in promoting it's culinary tourism. Singapore cuisines composed from the combination of various cuisines which are also popular in several countries, for example satay/sate, gulai kepala ikan, rojak/rujak (Indonesia), bak kut the, Hainan chicken rice (Cina), roti canai (India), and teh tarik (Malaysia).

Similar to Hongkong, Singapore is also has some annual event or festival in term of cuisines which is effectively boosting their tourism visit, e.g. Chili Festival [23], Singapore Food Festival, and World Gourmet Summit [13]. Large-scale international culinary festival are the greatest competitive advantage in culinary tourism because these events integrate local resources and profession from public and private sectors in bringing local cuisines onto the international stage [7].

Some of critical connection between food and tourism can be found in Singapore where both food and eating-out are treated as prominent tourism promotion theme. Singapore also has the policies in term of country's distinctive features [6]; [23]. According to Singapore Tourism Board, there are some dining theme in Singapore, e.g. Sky Dining (skyview dining in a cable-car), Tropical Garden Dining (dining in an excellent restaurant, located in a tropical garden), Waterfront Dining (dining in a restaurant near to canal, bay, river, lake, falls), Romantic Dining, etc.[23]. This kind of categorization prove that Singapore is realize its cuisine diversity and make some efforts to develope them seriously to be a unique item in their culinary tourism package.

The Singaporean government has taken several steps to promote gastronomy to become a world class tourist destination. It recognized that in order to be a world class tourist destination, it needed to build and develop the infrastructure including attractions, accomodations, and restaurants. The two main approaches were to develop it's culinary education and to promote its food through Singapore Tourism Board (STB) and Singapore International Culinary Exchange (SPICE). A program related to culinary education are providing trainings to Singaporeans in culinary, catering, and hospitality education. There is also a public vocational school (Temasek Polytechnic) worked with foreign culinary association (Culinary Institute of America) to initially design a three year diploma program in culinary and catering management, and then continued with developing the bachelor program [13].

\section{Gastronomy tourism in Malaysia}

Malaysia is also becoming one of the popular tourist destination in South East Asia. Tourism industry in Malaysia has become a major economic contributor. In 2002, a report released by The World Tourism Organization (WTO) stated that Malaysian tourist arrivals had grown at a rate double the world average between 1995 and 2002 [1]. Generally, Malaysia has some similarities with the other South East Asia countries, except Indonesia. Malaysia has limitation in area, natural resources, and other influencial factors in tourism. But in other side, Malaysia realized that there are still many advantages that can be used as the pull factors for tourists to visit Malaysia. With their slogan "Malaysia: Truly Asia", Malaysia has tried to explore their rich in culinary culture to support tourism sector development. Malaysian gastronomy aspects are the products of acculturation and assimilation among the various race particularly Malays, Chinese, Indian, and also other ethnic groups [9]. This condition has made the uniqueness and diversity in Malaysia local food and beverages and created a Malaysian cultural and gastronomical heritages. There is also a spesific ethnic-group in Malaysia 
called Mamak (Indian Moslem) whose popular food-preparation and cooking style, and has created the inter-racial dining like mee goreng mamak, pasembor, curries, roti canai, murtabak, sarmosa, lassi, teh tarik, and many more [8]; [9].

There are also several research conducted by Malaysian researchers about how to boost Malaysian Tourism through Malaysian gastronomy. In 2012, Zakariah et al had conducted a comparative study on Hongkong and Singapore tourism and tried to conclude some strategic implication to Malaysia's government policy [23]. The other study was about international tourists's perspective of Malaysian gastronomic products [9]; [10]. Those research's aims were to investigate the foreign (western) tourists's perception of Malaysian food, beverages, and food culture, even their level of satisfaction on Malaysian food and tourism service, supported with some statistical analysis tools; and also to highlight several important points that should be noted and addresed to the government authorities. A research about culinary art education by Zakaria et al discussed the importance of culinary art education to provide professional human resources in culinary [22]. Culinary education provider such as institutes, colleges, universities, small catering school, even secondary schools are potential partners for government in supporting the culinary tourism development in Malaysia.Through those institutions, Malaysian youths are encouraged to participate in exploring and developing local food and beverages intensively. For boosting the Malaysian gastronomy products internationally, the Malaysian Tourism Board also organize some cooking tours and promotions abroad through food ambassador, in collaboration with professional chefs. Another idea of the government on promoting Malaysian gastronomy is introducing and distributing the halal products internationally [9].

\section{Gastronomy tourism in Thailand}

It is nearly similar to Malaysia whose gastronomical characters are accumulated from several ethnics (Malay, China and Indian), Thailand's gastronomy profile is also an accumulation and assimilation from Chinese and Moslem culinary athmosphere. Although there were some influences from other culture, Thai cuisines have their own images and strong characters that are quite different from other countries. One of its famous cuisine is Thailand classical soup called tom yam [1]. People around the world have know it well as traditional cuisine from Thailand with unique taste and ingredients. Thailand gastronomic tourism involves culinary heritages base comes from the long history of Thai culinary heritages resources. A research on gastronomic tourism in Ayutthaya, Thailand, discovered that the most popular menus of Thai cuisines among Thai and foreign tourists are kouy tiew rue (Thai noodle soup with vegetable and meat), kung-mae-naam-poo (charcoal grilled river prawn), and roti-saai-mai, a Thai-Moslem dessert in the form of candy floss wrapped with bread flour [15]. Ayutthaya is now become one of food tourism destinations in Thailand, it has some food related events and also a unique attraction like Thai restaurants in the river markets. Tourism Authority of Thailand (TAT) have implemented many efforts in setting-up Thailand gastronomy, e.g. running a collaborative project with some culinary institutes, exploring and developing some innovative attraction like river market, and attempt to combine food, local souvenirs and cultures into a potential tourism experience for visitors. Potential of gastronomy tourism in Ayutthaya niche market has the strength point to the authentic multicultural products in the sense of cuisine [15].

\section{How about gastronomy potency in Indonesia?}

Compared with four countries above, actually Indonesia has more complete assets and advantages in culinary tourism. Indonesia has a wide area, high biodiversity, huge diversity in ethnics and tribes, various culture and tradition, and absolutely a wide spectrum of traditional cuisines. Indonesian traditional culinary is not only vary in every tribe and region, it was also categorized as dangerously delicious [20]. Besides, most of Indonesian traditional cuisines have the acceptable taste so they have the possibility to be loved by many people and society, including foreign tourists. The other advantage is that Indonesia is also popular for its natural and cultural tourism destination, so it always has a great amount of tourists visitation every year. By having 247 tribes, Indonesia has a ecoculinary potential to boost the tourism development [12], especially if every tribe and its cultural attribute are managed and developed seriously. Culinary tourism in Indonesia could be an integrated package with any attraction possesed by every tribe. Resumed from the description in this paper, this following table shows that essentially Indonesia has more 
potential chance and opportunities to develop culinary tourism (Table 1 ):

Table 1. Comparation of supporting factors in each countries

\begin{tabular}{|c|c|c|c|c|c|c|}
\hline No. & Factors & HK & Sing & Mal & Thai & Ind \\
\hline 1. & $\begin{array}{l}\text { Natural } \\
\text { resources }\end{array}$ & * & * & $*$ & $*$ & $* *$ \\
\hline 2. & $\begin{array}{l}\text { Human } \\
\text { resources }\end{array}$ & $*$ & $*$ & $*$ & $*$ & $* * *$ \\
\hline 3. & $\begin{array}{l}\text { Cultural } \\
\text { resources }\end{array}$ & $*$ & $*$ & $* *$ & $*$ & $* * *$ \\
\hline 4. & $\begin{array}{l}\text { Geographical } \\
\text { position }\end{array}$ & $*$ & $*$ & $*$ & $*$ & $* *$ \\
\hline 5. & $\begin{array}{l}\text { Tourism } \\
\text { destination }\end{array}$ & $*$ & $*$ & $*$ & $*$ & $* * *$ \\
\hline 6. & $\begin{array}{l}\text { Culinary } \\
\text { diversity }\end{array}$ & $*$ & $*$ & $*$ & $*$ & $* * *$ \\
\hline 7. & $\begin{array}{l}\text { Government } \\
\text { support }\end{array}$ & $* * *$ & $* *$ & $* *$ & $* *$ & $* *$ \\
\hline 8. & $\begin{array}{l}\text { Research \& } \\
\text { development }\end{array}$ & $* *$ & $*$ & $*$ & $*$ & $*$ \\
\hline 9. & $\begin{array}{l}\text { People's } \\
\text { involvement }\end{array}$ & $* *$ & $* *$ & $* *$ & $* *$ & $*$ \\
\hline
\end{tabular}

Bondan Winarno stated in his book, 100 Best Street Food of Indonesia, actually there are not any Indonesian cuisine can be claimed or called as the truly Indonesian food because essentially Indonesian cuisines are consisted of a very huge diversity of cuisines from a great amount of tribes and region in Indonesia [20]. So it can be stated that Indonesian cuisines is a representation and reflection of various kinds of cuisines owned by each tribe or region. Every tribe has its own traditional cuisines, and they have various kind of cuisines with various ingredients, way of preparation and serving, and absolutely vary in culture and tradition. Indonesian traditional culinary character is not just provincial, but it can be called as terroir (has a local characteristic in every region). For example, in West Sumatera province we can find sate Padang with three kinds of versions whose their own diferrences in taste, preparation, serving, and cultural origin, i.e. sate Padangpanjang, Pariaman, and Danguangdanguang [20]. There are still many case like this in other regions in Indonesia; not only in food, but also in beverages and munchies (snacks).

In 2012, The Ministry of Tourism and Creative Economy encouraged 30 Traditional Indonesian Culinary Icon. This was an effort to register and record the wealth of Indonesian traditional culinary culture handed down through generations [12]. Through this program, it is hoped that Indonesian culinary can be identified, documentated, and preserved so that the
Indonesian youth will realize that they have to pay attention for so many worthed heritages in culture and tradition. Culinary tourism can be used as one of the sectors in increasing the society prosperity through the provision of ingredients up to the serving process, and it also can create many opportunities for local people, like job vacancies, local economy rotation, economic activities, culinary business, and more supporting business related to culinary [12].

Plant natural resources becomes into something very important as the constituent of many elements of traditional Indonesian food. A high diversity of plant resources is also reflected in the diversity of plant species in the composition of Indonesian dishes. In many dishes even a lot of plants are the key species in the manufacture or preparation of the dish, and sometimes they can not be replaced by any other plant. The following table (Table 1) presents some Indonesian cuisines with the plant key species, with all the cuisines are taken from 30 Indonesia's tradisional culinary icon (IKTI) proposed by The Ministry of Tourism and Creative Economy:

Table 1 and Figure 1 shows that many plant species can not be substitute with other species because their important role as the ingredients of the dishes. Plants preservation in relation to archipelago culinary becomes something very crucial because it will influence the existence and sustainability of traditional Indonesian dish itself. This is compounded by the diversity of spices used, which along with other spices play an important role in shaping the flavor of a dish. Basically, the conservation of plant species is not only be applied just to the key species or main ingredients, but should be applied to the overall plant resources involved in the composition of traditional Indonesian dishes.

In relation to the principles of ecotourism focusing on eco-friendly values, involvement of local communities, and education aspects, ecotourism or culinary-based tourism is a package that can load these values. First, the eco-friendly value represented in species conservation (plants and animals) as the ingredients of the cuisines. Secondly, community involvement implemented in their participation in culinary-related activities and businesses as well as supporting business. Third, the educational aspects contained in the process of delivering information to visitors about Indonesian culinary knowledges, ranging from 
Table 1. Traditional Indonesian cuisines and the plant key species

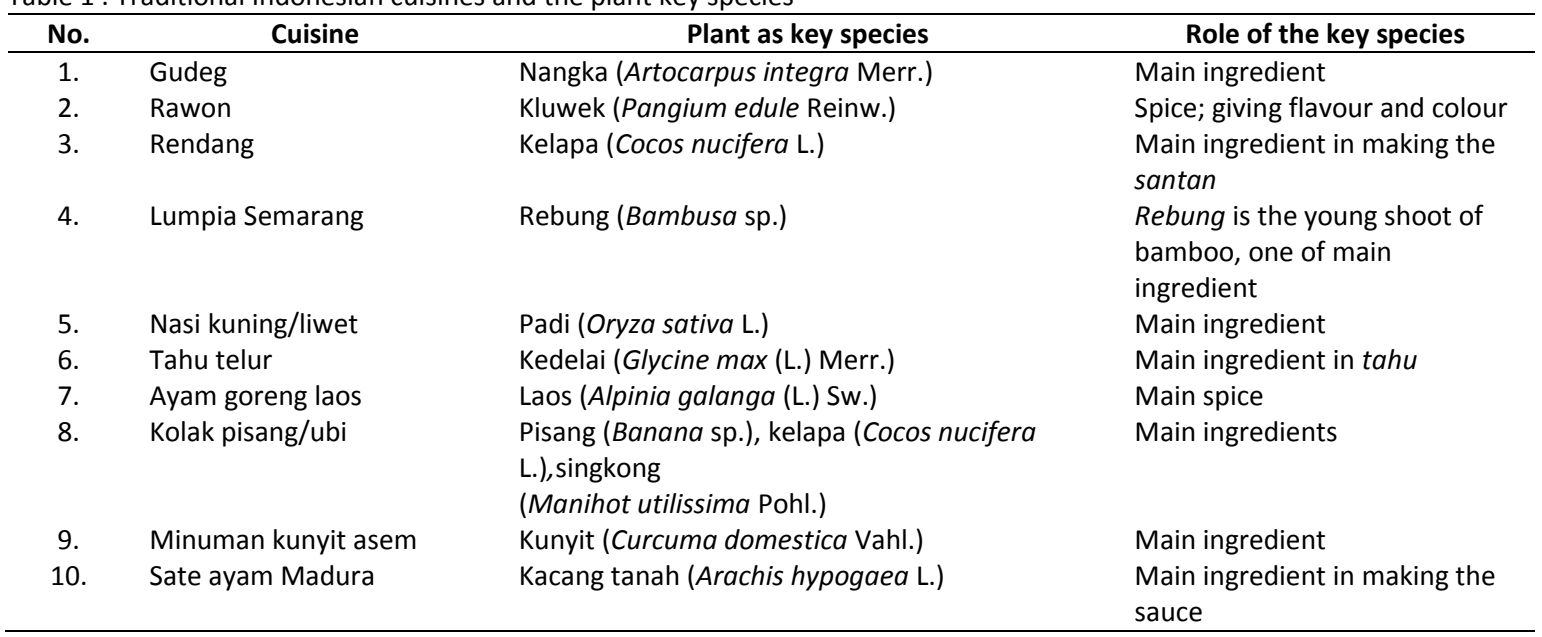

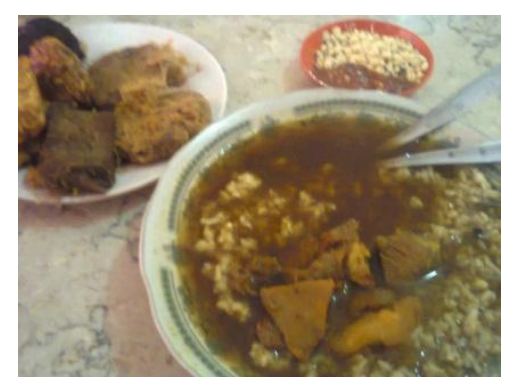

(a)

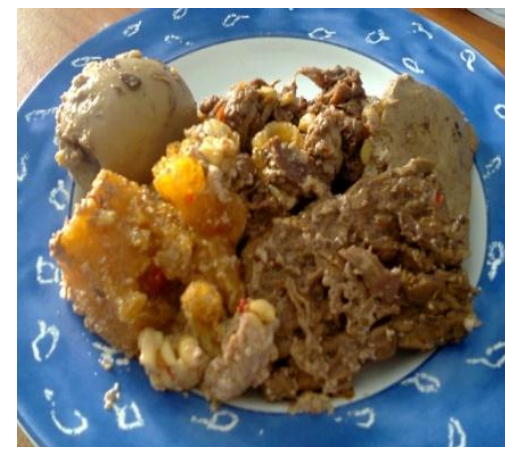

(c)

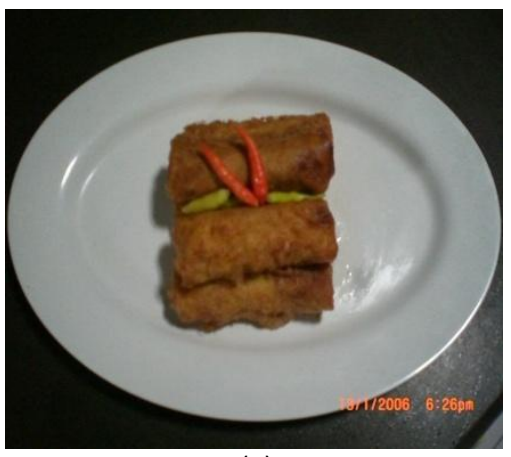

(e)



(b)

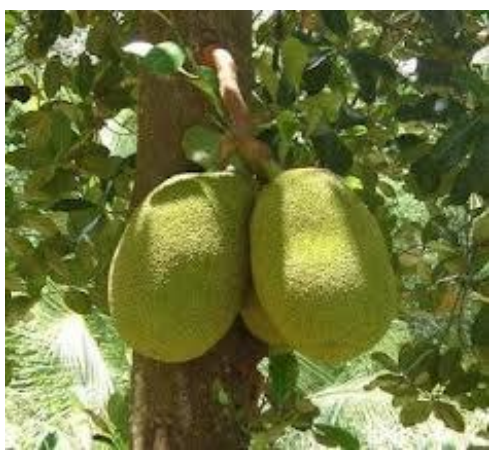

(d)

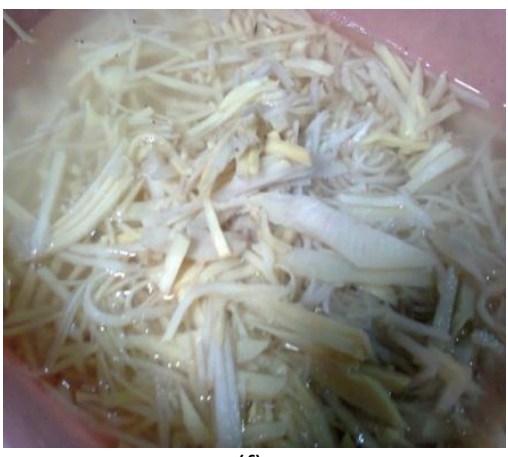

(f) 


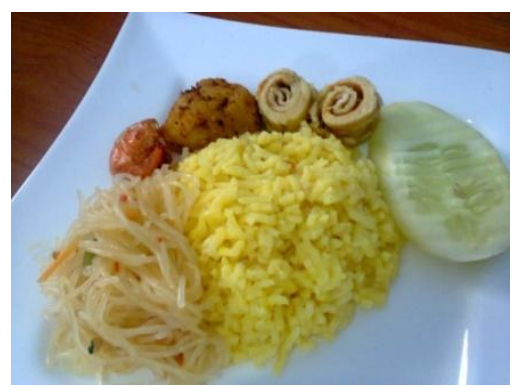

(g)

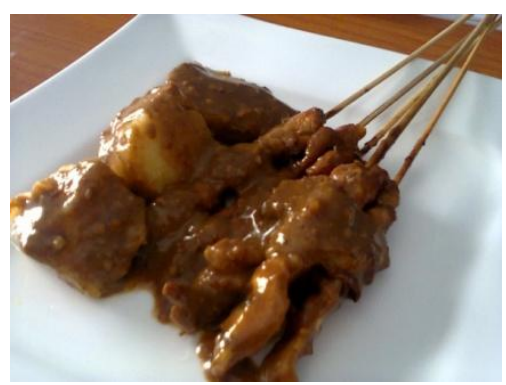

(i)

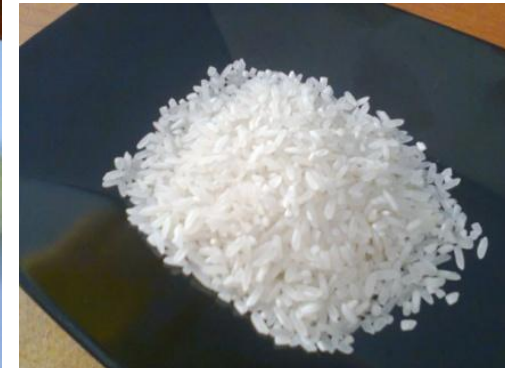

(h)

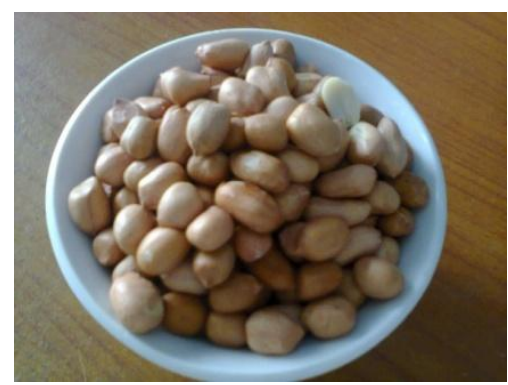

(j)

Figure 1. Traditional Indonesian cuisines and the plant key species: (a) Rawon, (b) Pangium edule Reinw., (c) Gudeg, (d) Artocarpus integra Merr., source: [8], (e) Lumpia Semarang, (f) young shoot of Bambusa sp., (g) Nasi Kuning, (h) Oryza sativa L., (i) Sate Ayam, (j) Arachis hypogaea L.

the variety of the cuisiness, constituent materials, preparation method, manner of presentation, and also the introduction of Indonesian culture and traditions contained in Indonesian culinary heritages.

With all of those bestows, Indonesia should be proud and realize that Indonesia's culinary can be explored, preserved and developed more intensive in order to be wellknown all over the world. Not just being wellknown, the development and introduction of Indonesian traditional cuisines with all the attributes will impacted on the conservation of Indonesia's culture and tradition related to Indonesia's culinary. This could be a good way in promoting Indonesia's culture and also an effort in conserving the worthed heritages of Indonesia. Indirectly, some effort in developing Indonesia's culinary will also boost the conservation on natural resources which is become the ingredients of the cuisines. In other words, developing Indonesia's traditional cuisines as an object of culinary or gastronomy tourism means that it will be give a promising impact in boosting the economic development, and also will be a good effort in conserving both the natural and cultural resources of Indonesia.

\section{Conclusions}

Gastronomy tourism, culinary tourism or food tourism is a form of tourism that is based on the strength owned by the culinary aspects of a country, region, or area. Gastronomy tourism is not only offer various types of dishes as an object of tourism attraction, but also includes a variety of food-related attributes ranging from constituent ingredients, preparation and processing method, manner of presentation, flavor aspects and nutritional contents, cultural values and traditions, as well as other information can be described by a type of dish.

Hong Kong, Singapore, Malaysia and Thailand are countries that have successfully explored and developed gastronomical aspects that becoming a great asset to support the tourism sector. Limitations of territory, natural resources, and other factors needed as the tourism capital has made gastronomy aspects of these countries becomes a potential option to support the advancement of tourism. Their governments successfully explore and develop the richness and uniqueness of their gastronomy character into a very good strength in attracting tourists visit. Many research were also conducted in those countries in order to study the potential efforts that may contribute the development in tourism. This awareness makes their tourism 
sector into an asset that enhanced the progress of the economy development.

Basically, Indonesia as a country with a large area, high biodiversity, various cultural traditions, has the greater opportunities and potential than those countries in developing the tourism. Indonesia's gastronomy with all its diversity and uniqueness is one of the potential tourist attraction that can support the tourism sector. Traditional cuisines with all its attributes are potential in supporting the development of tourism in a country, as far as the support of all the relevant sectors ranging from communities, the government, private agencies, institutions, and stakeholders. Through gastronomy tourism it can be expected a tourism activity that not only satisfy travelers in terms of food or drink, but also educate the tourists to be more responsive to the type of tourist attractions which are environmentally friendly, involving local communities, as well as having educational value. Gastronomy tourism can also be created into a form of ecotourism that can play a major role in the conservation of natural and cultural resources.

\section{Acknowledgement}

I would like to thank Luchman Hakim, S.Si., M.Agr.Sc., Ph.D for his guidance and suggestions regarding this paper, and also for the opportunity given to discuss this paper to be better.

\section{References}

[1]. Abdul-Karim, M. S., B. L. Chua, H. Salleh, 2010. Malaysia as a culinary tourism destination: International tourists' perspective. Journal of Tourism, Hospitality \& Culinary Arts 1 (3). pp. 63-78. ISSN 19858914

http://www.jthca.org/Download/pdf/V1\%2 0IS3/chap\%204.pdf

[2]. Canadian Tourism Comission. 2002. Acquiring a taste for cuisine tourism. A product development strategy. Canadian Tourism Comission, Ottawa.

[3]. Cornelius, E. G. 1979. Food Service Careers: The Food service industry and you. Bennet \& Mc Knight, Glencoe Publishing Company, California.

[4]. Enright, M., J. Newton. 2005. Determinants of tourism destination competitiveness in Asia Pasific: Comprehensiveness and universality. Journal of Travel Research, 43(4), 339-350.
[5]. Fox, R. 2007. Reinventing the Gastronomic Identity of Croatian Tourist destinations. Hospitality Management, 26 (3), 546-559.

[6]. Henderson, J. C. 2004. Fppd as a tourism resource: A view from Singapore. Tourism Recreation Research, 29(3), 69-74.

[7]. Horng, J. S., \& C. T. Tsai. 2012. Exploring marketing strategy of culinary tourism in Hongkong and Singapore. Asia Pacific Journal of Tourism Research, Vol. 17, No. 3, June 2012. http://www.tandfonline.com/doi/pdf/10.10 80/10941665.2011.25432 http://psasir.upm.edu.my/15519/

[8]. Jalis, M. H., Zahari, M. S., Othman, Z. 2007. Gastronomy products as tourist motivational factors: An opportunity to Malaysia. Proceeding of 2007 Tourism Educators of Malaysia Conference.

[9]. Jalis, M. H., M. Salehuddin, M. Zahari, M. I. Zulkifly, Z. Othman. 2009a. Malaysian gastronomic tourism products: Assesing the level of their acceptance among the western tourists. South Asian Journal of Tourism and Heritage, Vol. 2, No. 1.

[10]. Jalis, M. H., M. Salehuddin, M. Zahari, M. I. Zulkifly, Z. Othman. 2009b. Western tourists perception of Malaysian gastronomic products. Asian Social Science Vol. 5, No. 1 January 2009. www.ccsenet.org/journal.html

[11]. Kivela, J., J. C. Crotts. 2005. Gastronomy tourism: a meaningful travel market segment. Journal of Culinary Science \& Technology, 4(2/3), 39-55.

[12]. Marliyati, S. A., D. Hastuti, T. Sinaga. 2013. Eco-culinary tourism in Indonesia. in $\mathrm{F}$. Teguh \& R. Avenzora (Ed.). Ecotourism and sustainable tourism development in Indonesia: Potentials, lesson and best practices. Ministry of Tourism and Creative Economy, PT. Gramedia, Jakarta, Indonesia. pp. 251-301.

[13]. Mazza, G. M. C. 2013. Gastronomic tourism: Implication for Singapore. The Lauder Institute, University of Pennsylvania. USA. Research Paper.

[14]. Okumus, B. F. Okumus, B. Mckercher. 2007. Incorporating local and international cuisines in the marketing of tourism destination: The cases of Hong Kong and Turkey. Tourism Management, Vol. 28, pp. 253-261.

[15]. Pullphothong, L. \& C. Sopha, 2013. Gastronomic tourism in Ayutthaya, 
Thailand. International Jurnal of Business Tourism and Applied Sciences. http://www.ijbts-

journal.com/images/main_1366796758/004 3-Ladapha.pdf

[16]. Purba, F. H. K. 2012. Pemanfaatan Budidaya Buah Nangka (Artocarpus heterophyllus) dalam Pengembangan Agribisnis Indonesia. http://heropurba.blogspot.com/2012/12/p emanfaatan-budidaya-buah-nangka.html. Accessed in March 2014.

[17]. Richards, G. 2002. Gastronomy: an essential ingredient in tourism production and consumption? Routledge, London.

[18]. Singapore Tourism Board. 2008. Uniquely Singapore: Where to eat. Retrieved from http://visitsingapore.com/publish/stbportal /en/home/sub_landing_pages/Where_to_e at.html.
[19]. Winarno, B., 2013. 100 Best street food of Indonesia. PT Kompas Media Nusantara. Jakarta.

[20]. Wolf, E. 2002. Culinary Tourism: A Tasty Economic Proposition. Retrieved from http://www.culinarytourism.org.

[21]. Zakaria, M. A., S. H. A. Wahab, M. A. Jasmi. 2010. Culinary art education: A demanding profession in culinary tourism for Malaysian's New Economy Niche. Proceeding of the $1^{\text {st }}$ UPI International Conference on Technical and Vocational Education and Training. Bandung, Indonesia. 10-11 November 2010.

[22]. Zakariah, Z., R. K. Mohamad, W. Mohamad. 2012. Boosting Malaysian tourism - The food way! DOI: 10.7763/IPEDR. 2012. V55.36. http://www.ipedr.com/vol55/036ICEBM2012-K10055.pdf 